\title{
ANALISIS BIOAKTIF TANAMAN MANGROVE YANG EFEKTIF MEREDUKSI PENYAKIT BAKTERI PADA BUDI DAYA UDANG WINDU
}

\author{
Emma Suryati, Gunarto, dan Sulaeman
}

\begin{abstract}
ABSTRAK
Usaha penanggulangan penyakit pada komoditas perikanan pantai dewasa ini lebih diarahkan pada usaha diagnosis yang tepat dan cepat serta mencegah penggunaan vaksin serta pengelolaan mutu lingkungan melalui bioremediasi. Tanaman mangrove merupakan salah satu biota penyusun ekosistem pesisir pantai yang berfungsi sebagai tempat berlindung larva ikan dan biota lain serta sebagai penahan ombak dan angin, mereduksi kekeruhan, menstabilkan kandungan nitrat dan fosfat di dalam air, serta dapat menekan pertumbuhan populasi bakteri tertentu. Pemanfaatan bioaktif mangrove untuk mereduksi penyakit pada budi daya udang, perlu dianalisis untuk mengetahui jenis serta bioaktif mangrove yang dapat menekan pertumbuhan bakteri dan mikroorganisme lainnya. Metode analisis dilakukan dengan identifikasi jenis, ekstraksi, pemisahan, pemurnian senyawa aktif serta elusidasi struktur untuk mencari bahan aktif dan strukturnya terutama sebagai senyawa penuntun. Hasil penelitian menunjukkan bahwa delapan spesies tanaman mangrove yang efektif sebagai bakterisida. Fraksi yang paling aktif menghambat pertumbuhan bakteri yaitu fraksi air, EtOAC neutral, EtOAC asam. Hasil identifikasi isolat bioaktif tanaman mangrove antara lain Exoecaria agalocha yaitu Cyclohexasiloxane, Acanthus ilicifolius yaitu 2-methyl piperazin, Osbornia octodonta yaitu 2 heptanamin-6 methyl-amino-6 methylen, Avicenia yaitu Cyclopentasiloxane, Euphatorium inulifolium yaitu $n$-decane/ isodecane, Carbera manghas yaitu Furanon gamma-Crotonolactone dan Soneratia caseolaris yaitu L-galactopyranosida.
\end{abstract}

\section{ABSTRACT: Analysis of mangrove bioactive to reduce bacterium diseases of shrimp aquaculture. By: Emma Suryati, Gunarto, and sulaeman}

The effort of diseases controlling in fisheries commodity is emphasized to the accurate and rapid diagnosis as well as the use of vaccine and management of environment through bioremediation. Mangrove, one of the components of coastal ecosystems, has functions as shelters of many larvae, wave and wind prevention. The other functions are to reduce the turbidity, to stabilize nitrate and phosphate in the water and to inhibit the population growth of certain bacteria. The analysis of active component and structure of mangrove bioactive as lead compound was conducted by identification, extraction, isolation, purification, and structure elucidation method. The results showed that eight species of mangrove have been identified to show the activity as bactericide. The fractions showing the strong inhibition to the bacteria are water fraction, ethyl acetate neutral and ethyl acetate acid fraction. The identified bioactive compounds from mangroves are Cyclohexasiloxane isolated from Exoecaria agalocha, 2-methyl piperazin isolated from Acanthus ilicifolius, 2 heptanamin-6 methyl-amino-6 methylen isolated from Osbornia octodonta, Cyclopentasiloxane isolated from Avicenia, $n$-decane/isodecane isolated from Euphatorium inulifolium, Furanon gamma-Crotonolactone isolated from Carbera manghas and $L$. galactopyranosida from Soneratia caseolaris.

KEYWORDS: bioactive, mangrove, diseases, shrimp, bacteria

-) Peneliti pada Balai Riset Perikanan Budidaya Air Payau, Maros 


\section{PENDAHULUAN}

Penanggulangan penyakit pada budi daya udang dewasa ini lebih diarahkan pada usaha diagnosis yang tepat dan cepat, pencegahan melalui penggunaan vaksin serta pengelolaan mutu lingkungan melalui proses bioremediasi menggunakan mikroorganisme, tanaman air atau biota lain yang mempunyai kemampuan untuk itu. Ahmad et al. (1998a) melaporkan bahwa tanaman mangrove dapat dimanfaatkan sebagai bioremediator terutama dalam hal memperbaiki produktivitas tambak, mutu air yang layak, serta dapat mereduksi penyakit pada budi daya udang windu. Hal ini didukung dengan hasil penelitian yang dilakukan oleh Harahap (1997) mengenai kandungan bioaktif yang terdapat pada tanaman mangrove antara lain steroid dalam fraksi non polar yang bersifat bakteriostatik. Selain itu, telah didapatkan senyawa verbacosida dan turunan asam fenolat dari daun jeruju yang merupakan asosiasi tanaman mangrove (Soediro et al., 1996) dan senyawa flavonoid dan asam fenolat dari tumbuhan Rhizophora mucronata (Soediro et al., 1997). Beberapa jenis tanaman mangrove telah dimanfaatkan sebagai tanaman obat secara tradisional antara lain yang bermanfaat sebagai obat asma, diabetes, hepatitis, lepra, neuralgia, penyakit kulit, anti bisa, anti fertilitas, diare, antiseptik, paralisis, penyakit mata, dan penyakit infeksi lainnya, maka berdasarkan informasi tersebut, bioaktif yang ada pada tanaman mangrove dapat digunakan untuk menanggulangi penyakit yang sering menyerang pada budi daya perikanan, khususnya udang windu yang dibudidayakan secara lestari dan berwawasan lingkungan (Soediro, 1997).

Dari inventarisasi, dilaporkan jenis-jenis penyakit yang sering menyerang udang windu antara lain protozoa (Zoothamnium, Epystilis, Vorticella), jamur (Lagenidium, Fusarium), bakteri (Vibrio harveyi, V. alginoliticus), dan virus (Monodon Baculo Virus), terutama yang ditemukan di Sulawesi Selatan, Bali, dan Jawa (Atmomarsono et al., 1993; Lightner, 1996). Usaha penanggulangan penyakit oleh petambak dewasa ini, masih memanfaatkan bahan kimia dan pestisida, hal ini sangat merugikan karena dapat terjadi akumulasi dan pencemaran pada lingkungan. Untuk mengantisipasi hal tersebut, maka dicari metode penanggulangan yang cepat, tepat, akurat, dan berwawasan lingkungan antara lain melalui penggunaan bahan aktif yang mudah terurai, vaksin, serta pengelolaan mutu lingkungan yang memadai. Bahan yang mudah terurai di alam antara lain dari tumbuhan di antaranya saponin, rotenon, biji bengkuang, racun buah, umbi gladiol, dan Isotoma longiflora yang aktif sebagai racun dan bakterisida pada ikan (Suryati \& Hala, 1993). Sedangkan bahan dari laut seperti sponge, tunikata, karang lunak, hydrozoan, dan algae, dilaporkan mengandung bioaktif yang efektif sebagai bakterisida, fungisida, dan antibiofouling pada budi daya ikan dan udang (Suryati \& Ahmad, 1997; Muliani \& Suryati, 1998). Sponge, Callyspongia sp. aktif terhadap bakteri Aeromonas sp., Pseudomonas sp., dan Enterobacteriaceae, sedangkan Halichondria sp. dan Auletta sp. aktif menghambat pertumbuhan bakteri Vibrio sp. baik pada udang maupun pada ikan. Senyawa aktif tersebut telah diidentifikasi sebagai steroid dan turunan asam fenolat. Sponge yang aktif terhadap jamur dan biofouling yaitu Clathria sp., Thionella sp., Jaspis sp., Auletta sp., dan Xestospongia sp. (Suryati \& Parenrengi, 1998; Muliani \& Suryati, 1998).

Sedangkan usaha pencegahan terutama melalui penggunaan vaksin antara lain bakteri dan virus yang telah dilemahkan, serta pengelolaan mutu lingkungan yang diarahkan pada pengelolaan secara biologis yang berwawasan lingkungan melalui pemanfaatan mikroorganisme, dan tanaman sebagai bioremediator. Tanaman mangrove merupakan salah satu tanaman yang mampu memperbaiki mutu lingkungan di antaranya dapat mereduksi kekeruhan, dapat menstabilkan kandungan nitrat dan fosfat di perairan, serta dapat menekan populasi bakteri tertentu di perairan (Ahmad, 1998b). Selain itu juga dilaporkan bahwa mangrove mengandung senyawa steroid non polar yang bersifat bakteriostatik (Harahap, 1997).

Hal ini perlu diteliti lebih jauh mengenai isolasi dan identifikasi, penentuan golongan, struktur molekul senyawa polar maupun non polar secara keseluruhan, jumlah serta mekanisme bioaktif tanaman mangrove tersebut yang dapat mereduksi penyakit pada budi daya udang. Hasil akhir penelitian diharapkan diperoleh isolat aktif bioaktif mangrove yang dapat mereduksi penyakit pada budi daya udang windu serta struktur molekul bioaktif tersebut sebagai senyawa penuntun pembuatan senyawa sintesis.

Penelitian ini bertujuan untuk mengetahui senyawa bioaktif mangrove yang dapat 
mereduksi penyakit pada budi daya udang windu. Sedangkan tujuan khusus dari penelitian ini adalah mendapatkan isolat serta mengetahui senyawa bioaktif mangrove yang dapat mereduksi penyakit pada budi daya udang windu.

\section{BAHAN DAN METODE}

Tanaman mangrove dikumpulkan dari perairan yang berada di sekitar tambak udang, kemudian dipisahkan bagian tanamannya yaitu: daun, kulit batang, akar, buah, dan bunganya. Dikoleksi dalam keadaan segar lalu dikeringanginkan suhu $30^{\circ} \mathrm{C}$. Identifikasi nama, genus, spesies dilakukan di laboratorium menggunakan buku kunci Kitamura et al. (1998). Penapisan dilakukan dengan uji hayati menggunakan bioindikator isolat bakteri yang diisolasi dari udang dan tambak udang. Metode uji hayati yang digunakan yaitu metode difusi agar (Cowan, 1985). Data disajikan secara deskriptif

Isolasi dan pemurnian bioaktif mangrove yang dapat mereduksi penyakit pada budi daya udang dilakukan dengan cara ekstraksi, fraksionasi menggunakan pelarut polar dan non polar serta pemisahan secara kromatografi yaitu kromatografi lapis tipis (KLT), kolom terbuka dan preparatif menggunakan fasa diam silika gel GF 254 dan silika gel (C18) fasa terbalik (Harborn, 1973; Ikan, 1969). Aktivitas bioaktif mangrove yang diperoleh diuji menggunakan bioindikator bakteri. Uji kemurnian dilakukan menggunakan HPLC (Munson, 1984). Selajutnya isolasi dan identifikasi bioaktif mangrove yang terlarut di perairan yang mengacu pada hasil analisis kandungan bioaktif mangrove di laboratorium.

Elusidasi struktur dan identifikasi bioaktif mangrove diperoleh dari isolat bioaktif mangrove hasil pemurnian, diidentifikasi menggunakan reaksi penampak noda pada kromatografi lapis tipis untuk menentukan golongan dan sifat bioaktif, pengukuran panjang gelombang pada sinar ultra lembayung dan spektrum infra merah untuk menentukan gugus fungsi dari bioaktif, selanjutnya pengukuran berat molekul dan struktur dari bioaktif menggunakan GCMS (Munson, 1984).

\section{HASIL DAN BAHASAN}

Hasil penapisan dari 28 tanaman mangrove dan asosiasinya yang diuji aktivitasnya terhadap bioindikator yang digunakan yaitu beberapa spesies bakteri Vibrio yang diisolasi dari sediman, air, dan udang yang terkena penyakit antara lain bakteri Vibrio splendidus, $V$. metchikovii, $V$. mimicus, $V$. alginolyticus, $V$. harveyi, dan $V$. leiognathy, hasil penapisan tanaman tersebut diperoleh delapan spesies tanaman mangrove dan asosiatenya yang efektif menekan pertumbuhan bakteri Vibrio sp. pada budi daya udang antara lain tanaman, Avicenia alba. Acanthus ilicifolius, Carbera manghas, Clerodendron inerme Euphatorium inulifolium, Exoecaria agalocha, Osbornia octodonta, dan Soneratia caseolaris, masing masing aktif terhadap bakteri vibrio yang diisolasi dari sedimen tambak, air, dan udang yang terkena penyakit. Avicenia alba dan Clerodendron inerme aktif terhadap bakteri $V$. leognathy, Acanthus ilicifolius aktif terhadap bakteri $V$. costicola dan $V$ mimicus; Carbera manghas, dan Euphatorium inulifolium aktif terhadap bakteri $V$. splendidus dan $V$ methchicovi; Exoecaria agalocha aktif terhadap bakteri $V$ splendidus dan $V$ mimicus; Osbornia octodonta, dan Soneratia caseolaris aktif terhadap bakteri $V$ harveyi dan $V$. leiognathy (Tabel 1).

Pemurnian bioaktif tanaman mangrove yang dapat mereduksi penyakit pada budi daya udang, dilakukan terhadap tanaman mangrove yang aktif menghambat pertumbuhan bakteri yaitu Avicenia alba, Acanthus ilicifolius, Carbera manghas, Clerodendron inerme, Euphatorium inulifolium, Exoecaria agalocha, Osbornia octodonta, dan Soneratia caseolaris. Isolasi bioaktif dilakukan dengan fraksinasi menggunakan pelarut yang berbeda kepolarannya yaitu heksan, ethyl asetat asam. ethyl asetat netral, dan fraksi air. Hasil fraksinasi diperoleh fraksi aktif pada fraksi ethyl asetat asam yaitu Avicenia alba, Acanthus ilicifolius, Exoecaria agalocha, dan Osbornia octodonta, sedangkan yang aktif pada fraksi ethyl asetat netral yaitu Euphatorium inulifolium, dan yang efektif pada fraksi air yaitu Carbera manghas, Clerodendron inerme, dan Soneratia caseolaris (Tabel 2).

Hasil pemurnian menggunakan kolom kromatografi, menghasilkan fraksi aktif pada fraksi yang dicantumkan pada Tabel 3.

Hasil analisis isolat bioaktif masing-masing tanaman menunjukkan satu puncak kromatogram hal ini menunjukkan bahwa isolat tersebut merupakan isolat dengan satu komponen, kromatogram dari isolat tersebut dapat dilihat pada Gambar 1 -. 7 . 
Tabel 1. Penapisan tanaman mangrove yang efektif menekan pertumbuhan bakteri vibrio pada budi daya udang di tambak

Table 1. Screening result of mangrove plant the affective inhibition growth of Vibrio sp. bacteria on shrimp culture

\begin{tabular}{|c|c|c|c|c|c|c|}
\hline \multirow[t]{2}{*}{ Nama (Name) } & \multicolumn{6}{|c|}{$\begin{array}{c}\text { Daya hambat terhadap beberapa spesies } \\
\text { bakteri } \\
\text { Resistivity to some bacterium species }\end{array}$} \\
\hline & 2090 & 2097 & 3504 & 3519 & 3925 & 4036 \\
\hline Acanthus ilicifolius & $* k *$ & ** & $* *$ & $* * *$ & $* * *$ & $* *$ \\
\hline Avicenia marina & - & - & - & - & - & * \\
\hline Avicenia officinalis & - & - & - & - & - & $\Rightarrow$ \\
\hline Avicenia lanata & - & - & - & - & - & - \\
\hline Avicenia alba & - & - & $\cdot$ & - & - & $* * *$ \\
\hline Achrosticum aureum & $* *$ & $* *$ & - & * & 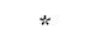 & $*$ \\
\hline Bruguiera gymnorhiza & - & - & - & - & - & $*$ \\
\hline Carbera manghas & $* *$ & 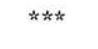 & * & * & * & * \\
\hline Clerodendron inerme & $*$ & - & - & - & - & $* * *$ \\
\hline Charchorus aestuans & $*$ & * & - & * & * & $*$ \\
\hline Derris trifoliate & - & - & - & - & - & - \\
\hline Euphatorium inulifolium & $\# * *$ & $\# * *$ & * & * & * & $*$ \\
\hline Exoecaria agalocha & $\approx * *$ & $* *$ & $* * *$ & $\# *$ & 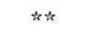 & $* *$ \\
\hline Finlasoinia maritime & - & - & - & - & - & - \\
\hline Hibiscus tiliaceus & - & - & - & - & - & - \\
\hline Ipomea pes-caprae & - & - & - & - & - & $\cdot$ \\
\hline Lantana camara & * & - & - & $* *$ & - & $* *$ \\
\hline Lumnitzera littorea & * & * & * & - & $*$ & $* \hbar$ \\
\hline Osbornia octodonta & $*$ & - & * & * & $m$ wkt & \#the \\
\hline Pongamia piñata & $\cdot$ & - & - & - & - & $*$ \\
\hline Rhizophora apiculata & $* k$ & * & - & * & - & - \\
\hline Sesuvium portulacastrum & - & $\cdot$ & * & * & - & - \\
\hline Soneratia caseolaris & $\# *$ & $*$ & - & $\cdot$ & $* * * \pi$ & $\# *$ \\
\hline Stachytorpheto jamaicensis & - & - & - & - & - & * \\
\hline Xylocarpus granatum & - & - & * & * & - & $\# *$ \\
\hline Tidak dikenal (Unidentified) & - & - & $\cdot$ & - & - & - \\
\hline Tidak dikenal (Unidentified) & - & - & - & - & - & - \\
\hline Tidak dikenal (Unidentified) & - & - & - & - & - & - \\
\hline
\end{tabular}

Keterangan (Remark):

2090 : Vibrio splendidus

2097 : Vibrio metsnicovii

3504 : Vibrio mimicus

(-) Tidak menghambat (No inhibition)

(*) Aktivitas rendah (Low activity)

${ }^{(* *}$ ) Aktivitas sedang (Weak activity)

$\left.{ }^{* * *}\right)$ Sangat aktif (Strong activity)
3519 : Vibrio alginolyticus

3925 : Vibrio harveyi

4036 : Vibrio leiognathy 
Tabel 2. Daya hambat hasil fraksinasi beberapa spesies tanaman mangrove terhadap bakteri vibrio pada budi daya udang

Table 2. Inhibition of fractination result some species of mangrove toward vibrio bacteria on shrimp culture

\begin{tabular}{lll}
\hline $\begin{array}{l}\text { Nama tumbuhan } \\
\text { Name of plant }\end{array}$ & $\begin{array}{l}\text { Fraksi akt if } \\
\text { Active fraction }\end{array}$ & $\begin{array}{l}\text { Nama bakt eri } \\
\text { Name of bact eria }\end{array}$ \\
\hline Acanthus ilicifolius & EtOac asam (EtOac of acid) & V.harveyi \\
Avicenia alba & EtOac as am (EtOac of acid) & V.leognathy \\
Carbera manghas & Fraksi air (Water fraction) & V.splendidus \\
Clerodendron inerme & Fraksi air (Water fraction) & V.leognathy \\
Euphatorium inulifolium & EtOac ne tral (EtOac of free) & V. splendidus \\
Exoecaria agalocha & EtOac asam (EtOac of acid) & V. mimicus \\
Osbornia octodonta & EtOac as am (EtOac of acid) & V.harveyi \\
Soneratia caseolaris & Fraksi air (Water fraction) & V.harveyi \\
\hline
\end{tabular}

Tabel 3. Hasil pemurnian bioaktif tanaman mangrove menggunakan kolom kromatografi serta aktivitasnya terhadap bakteri pada budi daya udang

Table 3. Purification result of mangrove plant bioactive used liquid chromatography and activity to bacteria on shrimp culture

\begin{tabular}{|c|c|c|c|}
\hline $\begin{array}{l}\text { Nama tumbuhan } \\
\text { Name of plant }\end{array}$ & $\begin{array}{l}\text { Fraksi aktif } \\
\text { Active fraction }\end{array}$ & $\begin{array}{l}\text { Kolom } \\
\text { Column }\end{array}$ & $\begin{array}{l}\text { Bakteri } \\
\text { Bacteria }\end{array}$ \\
\hline Acanthus ilicifolius & Fraksi air (Water fraction ) & Fraksi air (Waterfraction ) & V. harveyi \\
\hline Avicenia alba & ElOac asam (EtOac of acid) & Kolom ke 4-6 (Column to 4-6) & V. leognathy \\
\hline Carberamanghas & Fraksi air (Waterfraction) & Fraksi air (Water fraction) & V. splendidus \\
\hline Clerodendroninerme & Fraksi air (Waterfraction) & Fraksi air (Waterfraction) & V. leognathy \\
\hline Euphatorium inulifolium & EtOac netral (EtOac of free) & Kolom ke 8-R (Columnto 8-R) & V. splendidus \\
\hline Exoecaria agalocha & ElOac asam (EtOac of acid) & Kolom ke $1-24$ (Columnto $0-24$ ) & V. mimicus \\
\hline Osbomia octodonta & ElOac asam (EtOac of acid) & Kolom ke 7-8 (Column to 7-8) & V. harveyi \\
\hline Soneratia caseolaris & Fraksi air (Water fraction) & Fraksi air (Waterfraction) & V. harveyi \\
\hline
\end{tabular}

Hasil uji kemurnian menggunakan HPLC, menunjukkan bahwa senyawa bioaktif tanaman mangrove yang diisolasi memperlihatkan masing-masing satu puncak, hal ini menunjukkan bahwa senyawa yang diisolasi sudah relatif murni dan dapat dilanjutkan dengan analisis yang lebih lanjut yaitu penentuan sifat fisika kimia dan spektroskopi menggunakan UV-Vis spektrofotometer dan GC-MS.

Spektrum UV isolat murni yang diperoleh dari tanaman Avicenia alba, Acanthus ilicifolius, Avicenia sp., Exoecaria agalocha, Osbornia octodonta, Euphatorium inulifolium, dan Carbera manghas pada umumnya memperlihatkan adanya dua puncak yang menandai adanya dua atom $C$ yang terkonyugasi pada masing-masing senyawa yang diperoleh.
Hasil analisis menggunakan GC-MS memperlihatkan kandungan bioaktif dari masing-masing tanaman yang dominan antara lain diperoleh bahan aktif dari tanaman Exoecaria agalocha yaitu Cyclohexasiloxane, Acanthus ilicifolius yaitu 2-methyl piperazin, Osbornia octodonta yaitu 2 heptanamin- 6 methyl-amino-6 methylen, Avicenia yaitu Cyclopentasiloxane, Euphatorium inulifolium yaitu $n$-decane/isodecane, Carbera manghas yaitu Furanon gamma-Crotonolactone dan Soneratia caseolaris yaitu L galactopyranosida.

Uji pendahuluan toksisitas ekstrak mangrove ( $A$. alba, $E$. inulifolium, dan $O$. octodonta) terhadap larva udang windu ( $P$. monodon) menunjukkan toksisitas yang rendah. Konsentrasi sampai dengan $10.000 \mathrm{mg} / \mathrm{L}$ ekstrak mangrove menyebabkan mortalitas 


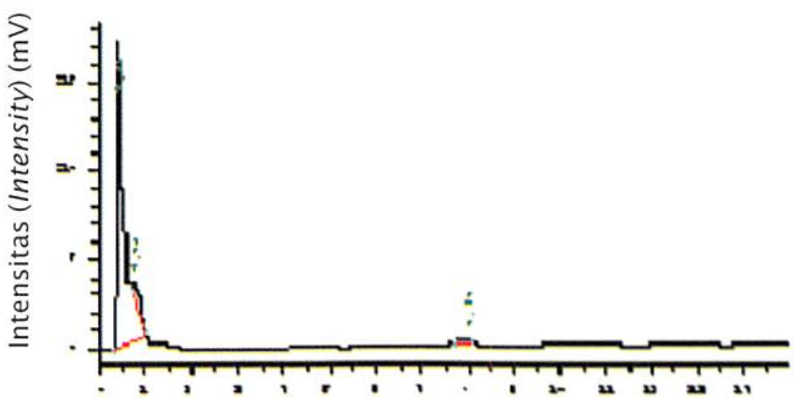

Waktu retensi (Retention time) ( $\mathrm{min}$ )

Gambar 1. Kromatogram isolat bioaktif dari Exoecaria agalocha

Figure 1. Chromatogram of bioactive from Exoecaria agalocha

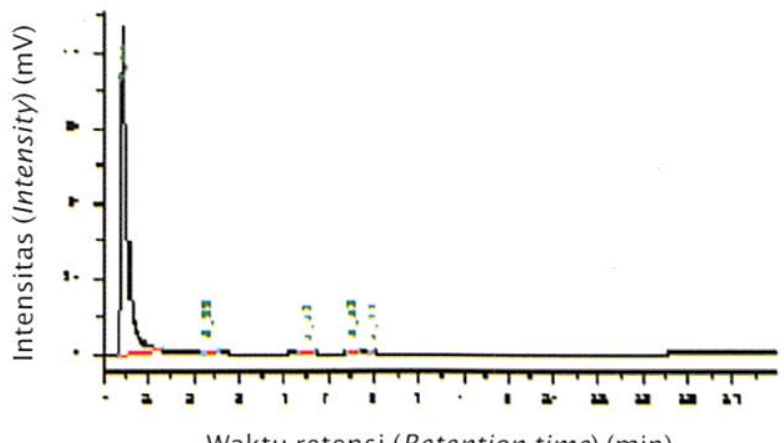

Waktu retensi (Retention time) (min)

Gambar 2. Kromatogram isolat bioaktif dari Acanthus ilicifolius

Figure 2. Chromatogram of Bioactive isolated from Acanthus ilicifolius

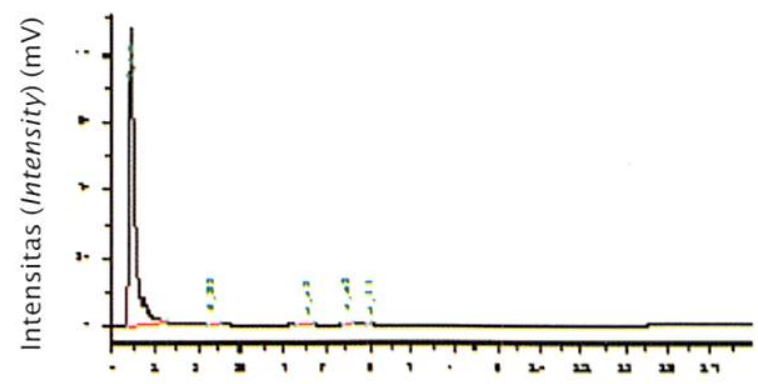

Waktu retensi (Retention time) (min)

Gambar 3. Kromatogram isolat bioaktif dari Osbornia octodonta

Figure 3. Chromatogram of bioactive isolated from Osbornia octodonta 


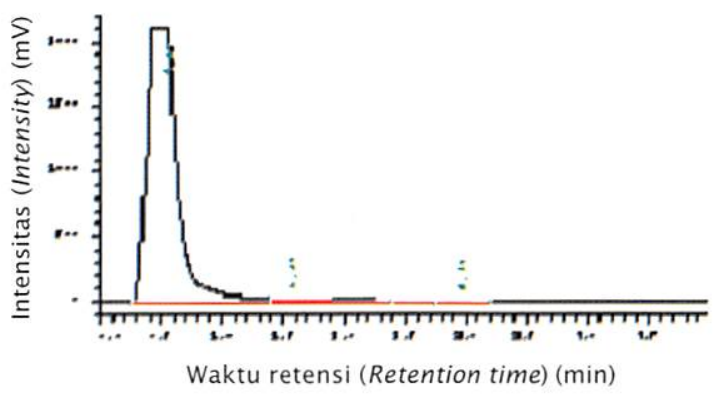

Gambar 4. Kromatogram isolat bioaktif dari Euphatorium inulifolium

Figure 4. Chromatogram of bioactive isolated from Euphatorium inulifolium

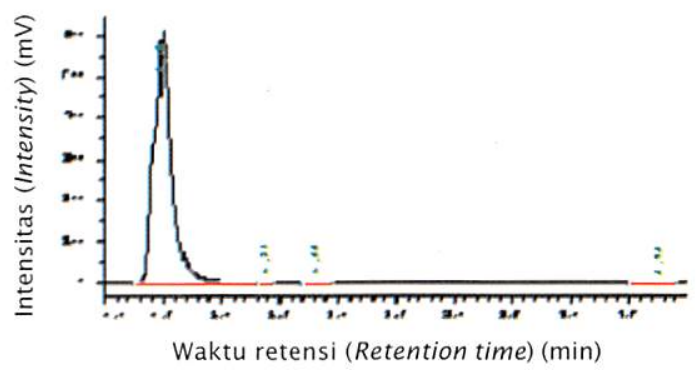

Gambar 5. Kromatogram isolat bioaktif dari Carbera manghas

Figure 5. Chromatogram of bioactive isolated from Carbera manghas

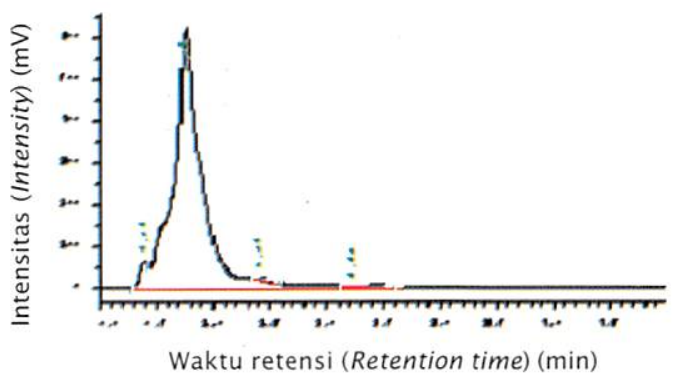

Gambar 6. Kromatogram isolat bioaktif dari Soneratia caseolaris

Figure 6. Chromatogram of bioactive isolated from Soneratia caseolaris

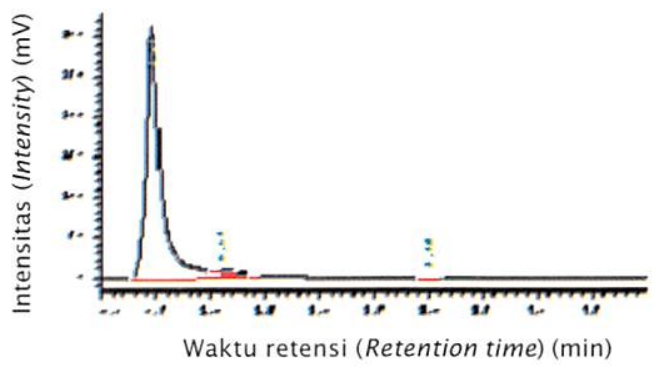

Gambar 7. Kromatogram isolat bioaktif dari Avicenia alba

Figure 7. Chromatogram of bioactive isolated from Avicenia alba 
larva udang windu hanya $10,0 \%$ untuk $A$. alba: $7,5 \%$ untuk $E$. inulifolium; dan $22,5 \%$ untuk $O$. octodata dalam waktu pengamatan $48 \mathrm{jam}$. Hasil tersebut mengindikasikan peluang yang besar dalam pemanfaatannya sebagai bakterisida pada pemeliharaan larva udang windu.

\section{KESIMPULAN}

Hasil penelitian memperlihatkan bahwa diperoleh 8 spesies tanaman mangrove yang efektif sebagai bakterisida. Fraksi yang paling aktif menghambat pertumbuhan bakteri yaitu fraksi air, EtOAC neutral, EtOAC asam. Hasil identifikasi Isolat bioaktif tanaman mangrove antara lain Exoecaria agalocha yaitu Cyclohexasiloxane, Acanthus ilicifolius yaitu 2-methyl piperazin, Osbornia octodonta yaitu 2 heptanamin-6 methyl-amino-6 methylen, Avicenia yaitu Cyclopentasiloxane, Euphatorium inulifolium yaitu n-decane/isodecane, Carbera manghas yaitu Furanon gammaCrotonolactone dan Soneratia caseolaris yaitu L-galactopyranosida.

Dengan ditemukan bioaktif mangrove yang dapat mereduksi penyakit, maka penanggulangan penyakit udang relatif dapat diatasi, sehingga produksi udang akan meningkat, dan budi daya dapat berlanjut secara lestari dan benwawasan lingkungan.

\section{DAFTAR PUSTAKA}

Ahmad, T. 1998a. Natural improvement of brackiswater ponds productivity. Seminar on Indonesia Marine Biotechnology I, 1415 Oktober 1998 LIPI, Jakarta, p. 85-98.

Ahmad, T. 1998b. The use of mangrove stands for shrimp ponds waste-water treatment. International Workshop on Brackishwater Mangrove Ecosystem.Productivity and sustainable Utilization. JIRCAS, Tsukuba, Japan.

Atmomarsono, M., M.I. Madeali, Muliani, dan A. Tompo. 1993. Kasus penyakit udang windu di Kabupaten Pinrang dalam Hanafi, A., M. Atmomarsono, dan S. Ismawati. Prosiding Seminar Hasil Penelitian Perikanan Budidaya Pantai, Maros, 16-19 Juli 1993, p. 35-40.

Cowan, S.T. 1985. Manual for the Identification of Medical Bacteria. Cambridge University Press. Cambridge, 456 pp.

Harahap, S. 1997. Analisis beberapa Senyawa Kimia dalam Fraksi n-Heksan dan Fraksi Benzen Kulit Batang Bakau Rhizophora mucronata Lamk. Thesis Pascasarjana, Universitas Hasanuddin, Ujung pandang, $48 \mathrm{pp}$.

Harborn, J.D. 1973. Phytochemical Methods. Chapman and Hill London, $354 \mathrm{pp}$.

Ikan, R. 1969. Natural Product a Laboratory Guide. Il ed. Academic Press san Diego, New York, Boston, London, Sydney, Tokyo, 359 pp.

Kitamura, S., C. Anwar, A. Chaniago, and S. Baba. 1998. Hand Book of Mangrove in Indonesia, Bali \& Lombok, 58 pp.

Lightner, D.V. 1996. A handbook of shrimp pathology and diagnostic procedures for diseases of cultured penaeid shrimp. The World Aquaculture Society, $312 \mathrm{pp}$.

Muliani dan E. Suryati. 1998. Isolasi Bioaktif bunga karang sebagai fungisida pada benih udang windu (Penaeus monodon). J. Pen. Per. Indonesia, 4(2):

Munson, J.W. 1984. Pharmaceutical Analysis Modern Methode. Part B. Marcel Dekker. Inc. The Upjohn Company. Kalamazoo, Michigan, $417 \mathrm{pp}$.

Soediro, S., K. Ruslan, I. Soediro, 1996. Verbaskosida dan asam fenolat dari daun jeruju (Acanthus illicifolius Linn. Acanthaceae) suatu tumbuhan mangrove. Seminar Interen Jur. Farmasi ITB, 18 pp.

Soediro, S., K. Ruslan, dan I. Soediro. 1997. Telaah kandungan senyawa flavonoid dan asam fenolat dalam kulit batang Rhizophora mucronata Lmk (Rhizophoraceae), suatu tumbuhan mangrove. Seminar Interen Jur. Farmasi ITB, 14 pp.

Soediro, S. 1997. Potensi dan manfaat tumbuhan mangrove sebagai sumber bahan bioaktif. Seminar Interen Jur. Farmasi ITB, $24 \mathrm{pp}$.

Suryati, E. dan Y. Hala. 1993. Bioaktivitas Isotoma longiflora terhadap bakteri Pseudomonas spp. pada ikan. Seminar IImiah Perikanan 30 Tahun FMIPA, Universitas Hasanuddin, 13 pp.

Suryati, E. dan T. Ahmad. 1997. Pemanfaatan sumberdaya alam non konvensional dari ekosistem perairan pantai. Prosiding Simposium Perikanan Indonesia II, 12 pp.

Suryati, Rosmiati, dan A. Parenrengi 1998. Analisis dan pemanfaatan senyawa bioaktif Stylaster sp. untuk bakterisida pada budidaya udang windu (Penaeus monodon) di hatchery. Prosiding Seminar Bioteknologi Kelautan I di Jakarta, 12 pp. 